\title{
Translational autocontrol of the Escherichia coli hfq RNA chaperone gene
}

\author{
BRANISLAV VEČEREK, ISABELLA MOLL, and UDO BLÄSI
}

Max F. Perutz Laboratories, Department of Microbiology and Immunobiology, University Departments at the Vienna Biocenter, 1030 Vienna, Austria

\begin{abstract}
The conserved bacterial RNA chaperone $\mathrm{Hfq}$ has been shown to play an important role in post-transcriptional regulation. Here,

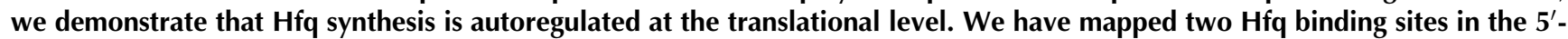
untranslated region of $h f q$ mRNA and show that $\mathrm{Hfq}$ binding inhibits formation of the translation initiation complex. In vitro translation and in vivo studies further revealed that $\mathrm{Hfq}$ binding to both sites is required for efficient translational repression of hfq mRNA.
\end{abstract}

Keywords: Hfq; translation; autogenous repression

\section{INTRODUCTION}

The Hfq protein was first recognized in Escherichia coli as a host factor required for replication of phage $\mathrm{Q} \beta$ (Franze de Fernandez et al. 1968). However, the importance of Hfq in cellular physiology was acknowledged just a decade ago when the broadly pleiotropic phenotypes of an E. coli hfq mutant were characterized (Tsui et al. 1994). The observations that Hfq is involved in expression of the rpoS gene encoding the stationary sigma factor, $\sigma^{38}$ (Brown and Elliot 1996; Muffler et al. 1996), stability control of several mRNAs (Tsui et al. 1997; Vytvytska et al. 2000; Folichon et al. 2003) and small regulatory RNAs (sRNAs) (Sledjeski et al. 2001; Moll et al. 2003a), posttranscriptional regulation of target mRNAs by sRNAs (Sledjeski et al. 2001; Massè and Gottesman 2002; Møller et al. 2002; Zhang et al. 2002; Večerek et al. 2003), that it acts as an RNA chaperone on mRNAs (Moll et al. 2003b; Geismann and Touati 2004), and as a virulence factor in several bacterial pathogens (Robertson and Roop 1999; Sonnleitner et al. 2003; Christiansen et al. 2004; Ding et al. 2004) have recently sparked a greater than ever interest in this highly conserved bacterial protein (for review, see Valentin-Hansen et al. 2004).

Electron microscope studies of the E. coli Hfa protein (Møller et al. 2002; Zhang et al. 2002) and X-ray

Reprint requests to: Udo Bläsi, Max F. Perutz Laboratories, Department of Microbiology and Immunobiology, University Departments at the Vienna Biocenter, Dr. Bohrgasse 9/4, 1030 Vienna, Austria; e-mail: Udo. Blaesi@univie.ac.at; fax: 43-1-4277-9546.

Article published online ahead of print. Article and publication date are at http://www.rnajournal.org/cgi/doi/10.1261/rna.2360205. crystallography of the Staphylococcus aureus (Schumacher et al. 2002) and Pseudomonas aeruginosa (Nikulin et al. 2005) Hfq homologs, as well as of the amino-terminal 72 amino acids of $E$. coli $\mathrm{Hfq}$ (Sauter et al. 2003) showed that it has a hexameric ring-shaped structure, and that it belongs to the large family of Sm-like proteins. These proteins primarily recognize short U-rich stretches (Achsel et al. 2001) and are involved in RNA processing in eukaryotic cells. An A/U-rich region preceded or followed by a stem-loop structure has similarly emerged as a common binding motif for $\mathrm{Hfq}$ (Brescia et al. 2003; Moll et al. 2003a; Geissmann and Touati 2004).

The Hfq protein forms hexamers in solution (Arluison et al. 2002) and is highly abundant ( $\sim 10,000$ Hfq-hexamers per cell; Valentin-Hansen et al. 2004), which in turn seems to account for its ability to affect multiple targets in the cell. In contrast to the Hfq synthesis rate, which was reported to be enhanced in exponentially growing cells when compared to stationary phase (Kajitani et al. 1994), it has also been reported that the total concentration of Hfq is higher in slow growing cells (Vytvytska et al. 1998) and upon entry into stationary phase (Tsui et al. 1997). The higher abundance of Hfq in stationary phase parallels the increased expression of sRNAs (Argaman et al. 2001; Zhang et al. 2003), many of which are targeted by Hfq. The E. coli hfq gene is part of the amiB-mutL-miaA-hfq-hflX-hflK-hflC operon, whose transcription is complex and driven by several promoters (Tsui and Winkler 1994). An internal heat-shock promoter serves the $h f q$ gene, which appears to ensure the maintenance of high level $h f q$ transcription under stress conditions (Tsui et al. 1996). 
Recent work revealed that Hfq binds to the $5^{\prime}$-end of ompA mRNA, encoding the outer membrane protein $A$, and changes its structure in a manner which is detrimental to translation initiation complex formation (Vytvytska et al. 2000; Moll et al. 2003b). Similarly, Hfq was shown to inhibit translation of $\operatorname{sodB}$ mRNA by mediating its interaction with the sRNA RyhB (Geissmann and Touati 2004). In both cases, the block of translation results in functional inactivation of the mRNA in an RNase E-dependent manner (Vytvytska et al. 2000; Massé et al. 2003). Given the important roles of Hfq in RNA metabolism, in this study we have addressed the question whether Hfq synthesis is subject to an autoregulatory circuit, wherein Hfq controls its own synthesis at the translational level.

\section{RESULTS AND DISCUSSION}

\section{Hfq binds to two sites in the $\mathbf{5}^{\prime}$-UTR of its mRNA}

Hfq has been reported to destabilize its own mRNA in an RNase E-dependent manner, suggesting that $h f q$ expression is autogenously regulated at the post-transcriptional level (Tsui et al. 1997). Therefore, we first employed gel-mobility shift assays to test whether Hfq binds to the $5^{\prime}$-UTR of its own transcript. As depicted in Figure 1A, $h f q 126$ RNA comprises the entire $5^{\prime}$-UTR up to nucleotide +57 , including two computer-predicted (Mathews et al. 1999) stem-loop structures with $\Delta \mathrm{G}$ values of -5.8 (h1) and $-15.6 \mathrm{kcal} / \mathrm{mol}$ (h2). Hfq binding to $h f q 126$ RNA resulted in two shifted bands, which suggested the presence of two distinct $\mathrm{Hfq}$ binding sites (Fig. 1B, panel I).

Hydroxyl radical footprinting was then used to map the Hfq-binding sites in the $5^{\prime}$-UTR of $h f q 126$ RNA. Two sites were protected by $\mathrm{Hfq}$ from hydroxyl radicals, the U-rich stretch at position -55 to -50 (Fig. 1A,C; Hfq binding site A) as well as the region between nucleotides -20 to +4 (Fig. 1A,C; Hfq binding site B), encompassing the ribosome binding site (RBS).

It has been reported that efficient $\mathrm{Hfq}$ binding to RNA requires stem-loop structures in the vicinity of the primary binding sequence (Brescia et al. 2003; Moll et al. 2003a; Geissmann and Touati 2004). Therefore, we tested by enzymatic probing with ribonuclease $\mathrm{T} 1$ whether both stem-loop structures shown in Figure 1A are present in $h f q$ mRNA (nucleotides -68 to +102 ). As shown in Figure 1D, T1 cleavage of this mRNA followed by subsequent primer extension revealed that the $G$ residues in $h 1$ and h2 were completely protected, indicating that both stem-loop structures are stable elements of the $5^{\prime}$-UTR of $h f q$ mRNA.

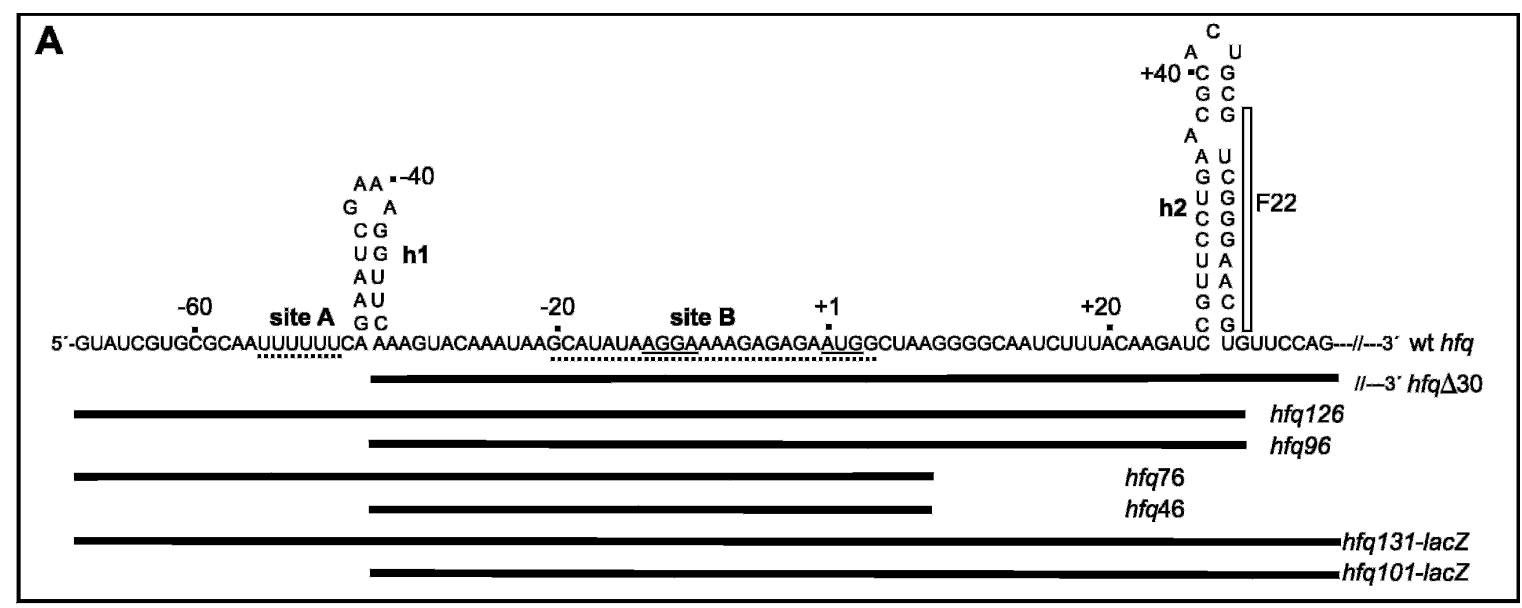

B
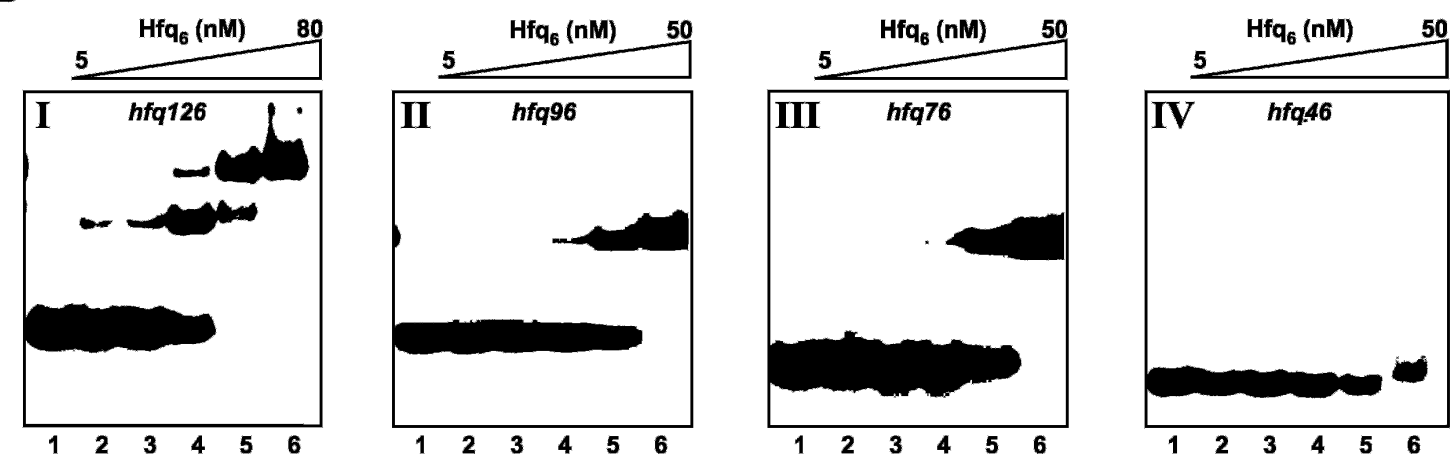

FIGURE 1. (Continued on next page) 
C

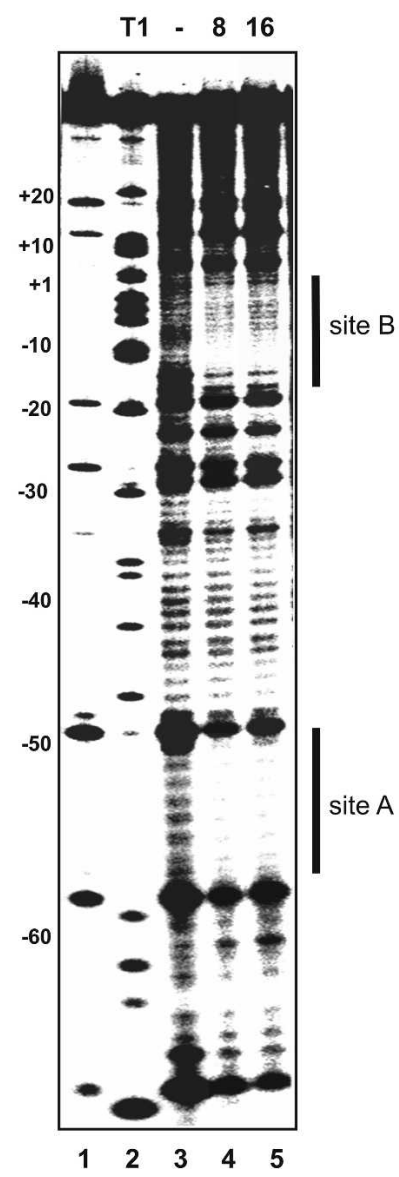

RNA) or the immediate coding region including h2 ( $h f q 76 \mathrm{RNA}$ ). Binding of Hfq to $h f q 96$ RNA resulted in only one shifted band in the gel-mobility shift assay (Fig. 1B, panel II) consistent with the absence of Hfq binding site A on this RNA. Binding of Hfq to $h f q 76$ RNA gave rise to mainly one shifted band as well (Fig. 1B, panel III), whereas the band likely resulting from two bound Hfa-hexamers was hardly discernible. The $h f q 76$ RNA is lacking h2, which could affect Hfq binding to site B. To test this further, band shifts were also performed with hfq46 RNA (Fig. 1A), which is devoid of the upstream $\mathrm{Hfq}$ binding site $\mathrm{A}$ as well as of h2. As shown in Figure 1B, panel IV, Hfq did not bind to this RNA indicating that Hfq binding to site $\mathrm{B}$ requires the stem-loop structure. Since we did not observe a significant difference in the binding affinity of $\mathrm{Hfq}$ for either site on the $h f q 96$ or the $h f q 76$ transcript (Fig. 1B, panel II,III), these gel-mobility shift assays suggested that both sites are occupied by Hfq without preference, rather than in a cooperative manner. Moreover, it seems likely that the faster migrating $h f q 126$ complex (Fig. 1B, panel I) is a mixture of $h f q 126$ transcripts, where Hfq is bound either to site A or B.

FIGURE 1. Hfq has two binding sites in the $5^{\prime}$-UTR of $h f q$ mRNA. (A) Primary structure of the $h f q 5^{\prime}$-UTR and the $5^{\prime}$-initial coding region containing two stem-loop structures h1 and h2 $($ see $D)$. The SD sequence and the start codon are underlined. Regions protected by Hfa from hydroxyl radical cleavage (see $C$ ) are shown by dotted lines below the sequence. The binding site of the F22 oligonucleotide used in the toeprinting assay shown in Figure $2 \mathrm{C}$ is indicated. The $h f q 126, h f q 96, h f q 76$, and $h f q 46$ mRNA fragments used in the gel-mobility shift assays shown in $B$ are depicted by black lines. The $5^{\prime}$-terminal portions of the $h f q \Delta 30$ mRNA used for in vitro translation and that of the $h f q 131-l a c Z$ and $h f q 101-l a c Z$ fusion genes are also shown. (B) Hfq binding to $h f q 126, h f q 96, h f q 76$, and $h f q 46$ mRNA fragments. $5^{\prime}$-end labeled transcripts $(5 \mathrm{nM})$ were incubated in the absence (lane 1) or in the presence of increasing molar ratios of Hfq. The Hfq-hexamer $\left(\mathrm{Hfq}_{6}\right)$ concentrations in panel $I$ were $5 \mathrm{nM}, 10 \mathrm{nM}, 20 \mathrm{nM}$, $40 \mathrm{nM}$, and $80 \mathrm{nM}$ (lanes 2-6) and in panels $I I-I V$ were $5 \mathrm{nM}, 10 \mathrm{nM}, 20 \mathrm{nM}, 30 \mathrm{nM}$, and 50 nM (lanes 2-6). (C) Hydroxyl radical footprints of $h f q 126$ mRNA in the presence of Hfq. Samples containing $5^{\prime}$-end-labeled $h f q 126$ mRNA were incubated in the absence (lane 3 ) or in the presence of Hfq (lanes 4,5) and subjected to hydroxyl radical cleavage. Hfq was added in eightfold (lane 4) and 16-fold (lane 5) molar excess (Hfq $\mathrm{H}_{6}$ excess) over $h f q 126$ mRNA. Lane 1 , untreated $h f q 126$ mRNA $(5 \mathrm{nM})$ was incubated with Hfq $\left.(80 \mathrm{nM} \mathrm{Hfq})_{6}\right)$. Lane 2, RNase T1 cleavage (G-specific cleavage) of $h f q 126 \mathrm{mRNA}$. The regions protected from hydroxyl-radical cleavage by Hfq (sites A and B) are marked by bars (see also $A$ ). Nucleotide positions are given at the left. $(D)$ RNase T1 probing of secondary structures within the $5^{\prime}$-UTR and $5^{\prime}$-initial coding region of $h f q$ mRNA. The $h f q$ mRNA was hybridized to $5^{\prime}$-end labeled primer Y19 and then subjected to RNase T1 cleavage. The cleavage sites were mapped by primer extension. The reactions were incubated in the absence (lane 7) or in the presence of $0.1 \mathrm{U}$ (lane 5) and $0.5 \mathrm{U}$ (lane 6) of RNase $\mathrm{T} 1$, respectively. The $\mathrm{G}$ residues protected from RNase $\mathrm{T} 1$ cleavage are numbered relative to the $\mathrm{A}(+1)$ of the start codon of $h f q$ mRNA and are marked by open arrowheads. Regions corresponding to stem-loop structures $\mathrm{h} 1$ and $\mathrm{h} 2$ are depicted by bars at the left. Lanes $1-4$, sequencing reactions.

Next, band shift assays were performed with $h f q 126$ RNA derivatives (Fig. 1A) lacking either the $5^{\prime}$-terminal part ( $h f q 96$

\section{Autogenous repression of $h f q$ mRNA translation}

Translational repressors inhibit formation of the translation initiation complex between 30 S ribosomes, initiator-tRNA, and mRNA. This can occur by direct competition with 30S subunit binding (Romby and Springer 2003), as in the cases of R17 coat protein, T4 gene 32 protein, T4 regA protein, and threonyltRNA synthetase, or by entrapment of the $30 \mathrm{~S}$ subunit in an unproductive binary complex with mRNA, as exemplified by ribosomal proteins $\mathrm{S} 15$ and $\mathrm{S} 4$ (Philippe et al. 1993; Schlax et al. 2001).

To test whether Hfq acts as an autogenous translational repressor, we first used an E. coli S30 in vitro translation system and programmed it with both full length $h f q$ and $p p i B$ (control) mRNAs in the presence of increasing concentrations of Hfq. The ppi mRNA, encoding rotamase B, was used as a control 
A

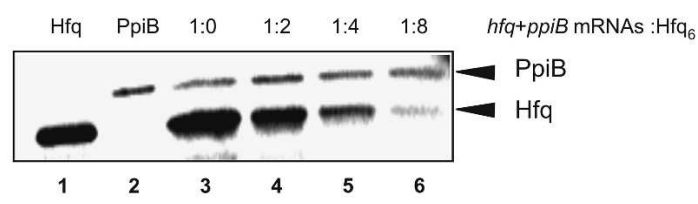

B

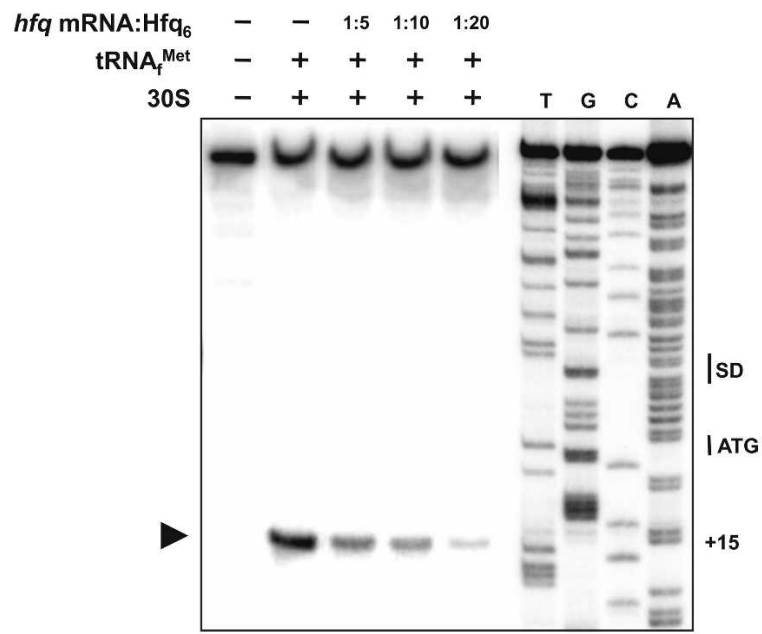

C

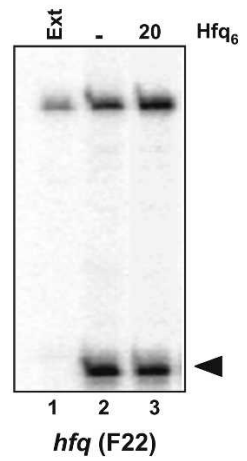

D

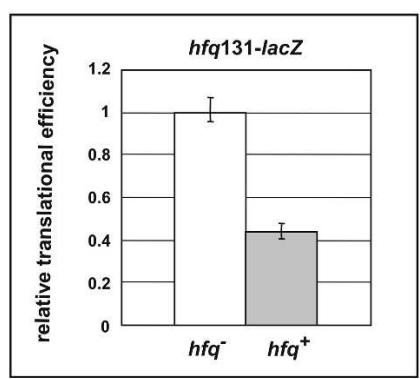

FIGURE 2. Hfq represses translation of its own mRNA. (A) Hfq inhibits in vitro translation of $h f q$ mRNA. Equimolar concentrations (100 nM) of full length $h f q$ and $p p i B$ mRNAs were used for in vitro protein synthesis as described in Materials and Methods. The translation reactions were carried out in the absence (lane 3) and in the presence (lanes 4-6) of increasing molar amounts of Hfq to both mRNAs as indicated on top of the autoradiograph (ratios correspond to molar excess of $\mathrm{Hfq}_{6}$ over totally added mRNA). Lanes 1 and 2, in vitro translation of $h f q$ and $p p i B$ mRNA in the absence of Hfq, respectively. The positions of the $\left[{ }^{14} \mathrm{C}\right]$-labeled $\mathrm{Hfq}$ and PpiB proteins are indicated by arrowheads. $(B)$ Autogenous inhibition of translation initiation by Hfa. The toeprinting reactions were performed as described in Materials and Methods. Lane 1, primer extension in the absence of $30 \mathrm{~S}$ subunits, $\mathrm{tRNA}_{\mathrm{f}}^{\text {Met }}$, and Hfq. Lane 2, toeprinting in the presence of $30 \mathrm{~S}$ subunits, tRNA $\mathrm{f}_{\mathrm{f}}^{\mathrm{Met}}$, and absence of Hfq. Lanes 3-5, toeprinting with $30 \mathrm{~S}$ subunits, $\mathrm{RNA}_{\mathrm{f}}{ }^{\mathrm{Met}}$, and in the presence of increasing molar Hfq-hexamer ratios to $h f q$ mRNA as indicated on top of the autoradiograph. Hfq was added prior to the addition of ribosomes. The arrowhead depicts the toeprint signal at position +15 relative to the A of the ATG start codon. The relevant part of the DNA sequence of the $h f q 5^{\prime}$-UTR is shown at the right. The position of the Shine and Dalgarno (SD) sequence and of the ATG start codon is indicated. (C) Lack of ribosome binding to $h f q$ mRNA annealed to F22 oligonucleotide. In vitro toeprinting assay was performed on $h f q$ mRNA after annealing of oligonucleotide F22 as described in Materials and Methods. Lane 1, primer extension (Ext) in the absence of $30 \mathrm{~S}$ subunits, $\mathrm{tRNA}_{\mathrm{f}}^{\text {Met }}$, and Hfq. Lane 2, toeprinting in the presence of $30 \mathrm{~S}$ subunits, tRNA $\mathrm{f}_{\mathrm{f}}^{\text {Met }}$, and in the absence of Hfq. Lane 3, toeprinting with $30 \mathrm{~S}$ subunits, $\mathrm{tRNA}_{\mathrm{f}}{ }^{\mathrm{Met}}$ in the presence of a 20 -fold molar excess of $\mathrm{Hfq}$ (Hfa $\mathrm{Hatio}_{6}$. The arrow indicates the position of the toeprint signal(s). (D) The relative translational efficiency of the $h f q 131$-lacZ gene depends on Hfq. The expression of $h f q 131-l a c Z$ fusion was induced as described in Materials and Methods. The averaged $\beta$-galactosidase values normalized to mRNA levels obtained in the $h f q^{-}$strain (control) was set to 1 (white bar). The value obtained with the $h f q^{+}$strain (gray bar) was normalized to the control. The experiment was performed in duplicate. The error bars represent standard deviations.

because we had recently shown that Hfq neither affects in vitro translation initiation complex formation nor in vitro translation of this mRNA (Večerek et al. 2003). The translation of $h f q$ mRNA decreased concomitantly with increasing amounts of Hfq and was significantly repressed when Hfq was added in an eightfold (Hfq-hexamer) molar excess over both mRNAs (Fig. 2A). In contrast, translation of ppiB mRNA continued unabated (Fig. 2A), indicating that Hfq acts specifically on its own mRNA.

Next, we used an in vitro toeprinting assay (Hartz et al. 1988 ) to test directly whether Hfq prevents translation initiation complex formation on its own mRNA by impeding ribosome binding. Hfq was added to a $h f q$ transcript spanning nucleotides -68 to +102 prior to the addition of ribosomal subunits and initator-tRNA at different molar ratios of
Hfq (Hfq-hexamer) to mRNA. As shown in Figure 2B, the toeprint signal obtained after extension of primer Y19 decreased with increasing concentrations of $\mathrm{Hfq}$, and formation of the $30 \mathrm{~S}$ translation initiation complex was strongly diminished when Hfq was added in a 20 -fold molar excess to mRNA. Previous toeprinting experiments conducted with $E$. coli lpp mRNA (Vytvytska et al. 2000) and, as mentioned above, with $p p i B$ mRNA (Večerek et al. 2003) demonstrated that $\mathrm{Hfq}$ did not inhibit ribosome binding per se-i.e., Hfq has no general detrimental effect on translation initiation. We therefore considered this inhibitory effect of Hfq to be specific for $h f q$ mRNA rather than simply reflecting the high affinity of Hfq for RNA (Senear and Steitz 1976).

Since the band shift experiments (Fig. 1B) implicated the stem-loop structure h2 (Fig. 1A) in Hfq binding to site B, 
which includes the ribosome binding site, we also asked whether $\mathrm{h} 2$ is of importance for translational auto-repression of $h f q$ mRNA. We tested this possibility by performing a toeprinting experiment on $h f q$ mRNA after annealing of oligonucleotide F22. F22 is complementary to the $3^{\prime}$ part of the stem of h2 (see Fig. 1A). Hence, binding of this oligonucleotide to $h f q$ mRNA should result in melting of the structure. The occurrence of an extension signal-i.e., the generation of a cDNA by reverse transcriptase primed by oligonucleotide F22 (Fig. 2C, lane 1)-demonstrated that the oligonucleotide was bound to $h f q$ mRNA (nucleotides -68 to +102$)$. Consistent with the idea that Hfq binding to site $\mathrm{B}$ depends on $\mathrm{h} 2$, the protein did not inhibit ribosome binding on $h f q$ mRNA annealed to oligonucleotide F22. Even a 20-fold molar excess of Hfq (hexamer) to mRNA resulted in a strong toeprint signal primed with oligonucleotide F22 (Fig. 2C, lane 3). In other words, in the absence of the stemloop structure Hfq was apparently unable to abolish translation initiation complex formation.

To verify these in vitro data, the inducible plasmid-born hfq131-lacZ reporter gene (see Fig. 1A) was constructed, wherein the first $131 \mathrm{nt}$ of $h f q$ mRNA were fused to the eighth codon of the lacZ gene. The synthesis of the Hfq $\Phi$ LacZ protein was monitored in a $h f q^{+}\left(\mathrm{MC} 100 \mathrm{~F}^{\prime}\right)$ and in a $h f q^{-}$ $\left(\mathrm{AM}_{\left.111 \mathrm{~F}^{\prime}\right)}\right.$ genetic background. The $\beta$-galactosidase activities were determined in each strain from samples taken 30 min after induction of the hfq131-lacZ gene. To account for possible variables, such as mRNA levels and/or mRNA stability or plasmid copy numbers in the $h f q^{+}$and $h f q^{-}$strains, the $\beta$-galactosidase activities were normalized to the respective hfq131-lacZ mRNA concentration, which in turn was normalized to $5 \mathrm{~S}$ ribosomal RNA. As shown in Figure 2D, in the $h f q^{+}$strain, the relative translational efficiency of the $h f q 131$ lac $Z$ mRNA was only $\sim 44 \%$ of the synthesis obtained in the $h f q^{-}$strain. Taking into consideration this in vivo experiment and the in vitro experiments (Fig. 2A,B), we concluded that $\mathrm{Hfq}$ acts as an autogenous translational repressor.

\section{Both Hfq binding sites $\mathrm{A}$ and $\mathrm{B}$ contribute to translational auto-repression}

Next, we asked whether both binding sites in the $5^{\prime}$-UTR of $h f q$ could act synergistically in translational auto-repression. We first compared the translational yield of equimolar concentrations of $h f q$ wild-type mRNA and $h f q \Delta 30$ mRNA (Fig. 1A), which lacks Hfq binding site A, in the presence of increasing amounts of $\mathrm{Hfq}$ in an in vitro translation assay. As shown in Figure 3A, Hfq repressed translation of both mRNAs to a different extent. An $\sim 1.5$-fold and a threefold molar excess of Hfq (hexamer) over $h f q$ wild-type mRNA and $h f q \Delta 30$ mRNA, respectively, was required to reduce the translational yield to $50 \%$. Hence, $h f q \Delta 30$ mRNA was $\sim$ twofold less sensitive to Hfq repression when compared with wild-type mRNA, implicating Hfq binding site $\mathrm{A}$ and $\mathrm{h} 1$ in translational auto- repression. Hydroxyl radical footprinting of $h f q 96$ mRNA was then performed in the presence of Hfq to demonstrate that the deletion of site A did not change the structure of the $h f q 5^{\prime}$-UTR and that Hfq still binds to site B. As shown in Figure $3 \mathrm{~B}$, this experiment did not reveal any changes in the protection of binding site B by Hfq (see Fig. 1C). We therefore interpreted the in vitro translation data as showing that both sites are required for efficient translational repression of $h f q$ mRNA.

For verification, we compared the relative translation rate of $h f q 131-l a c Z$ mRNA (Fig. 1A) with that of $h f q 101-$ lacZ mRNA (Fig. 1A) in vivo. The hfq101-lacZ mRNA corresponds at the $5^{\prime}$-end to $h f q \Delta 30 \mathrm{mRNA}$, and thus lacks Hfq binding site A. As mentioned above, to account for variables in both genetic backgrounds the $\beta$-galactosidase activities obtained with the $h f q 101-l a c Z$ construct in a $h f q^{+}$and a $h f q^{-}$strain, respectively, were again normalized to the respective mRNA levels, which in turn were normalized to $5 \mathrm{~S}$ rRNA. There was no significant difference in the relative translational efficiency of $h f q 131-l a c Z$ mRNA and $h f q 101-l a c Z$ mRNA in the $h f q^{-}$strain (data not shown). However, as shown in Figure $3 \mathrm{C}$, the expression of the $h f q 101-l a c Z$ gene was significantly less affected than that of the $h f q 131-l a c Z$ gene (see Fig. 2D) in the $h f q^{+}$strain when compared to the $h f q^{-}$strain.

Taken together, the results shown in Figure 3 implicated both Hfq binding sites A and B in translational repression, although only binding site B overlaps with the RBS of the $h f q$ mRNA. In addition, the stem-loop structure h2 in the immediate coding region is apparently required for $\mathrm{Hfq}$ binding to site B (Figs. 1B, 2C). How can we account for the contribution of Hfq binding site A in translational autorepression? Biochemical studies have suggested that two Hfqhexamers can form a dodecamer (Arluison et al. 2002), possibly through interactions of the non-polar surface of each hexamer (Schumacher et al. 2002). The Hfq-dodecamer would have RNA binding site(s) on either surface, and thereby could interact with the two Hfq binding sites A and B. In a simplistic view this Hfa-dodecamer complex could be more stable and thus inhibit ribosome loading more efficiently than a hexamer bound to site B alone. Similarly to Hfq, the E. coli global regulator CsrA has been demonstrated to interfere with translation initiation on $g l g C$ (Baker et al. 2002) and cstA (Dubey et al. 2003) by binding to two and three or four binding sites, respectively. Although the contribution of the respective CsrA binding sites to translational repression remains to be elucidated, in either case CsrA-CsrA interactions have been suggested to contribute to complex formation with the respective mRNAs.

The steady state level of $h f q$ mRNA was shown to depend on the major E. coli RNA endonuclease, RNase E (Tsui and Winkler 1994). Although the levels of RNase E were reportedly unchanged in a $h f q^{-}$strain, the half-life of $h f q$ mRNA was 5.8 min more than threefold higher in a $h f q^{-}$mutant than in the isogenic $h f_{q}^{+}$strain (1.8 min; Tsui et al. 1997). 
A
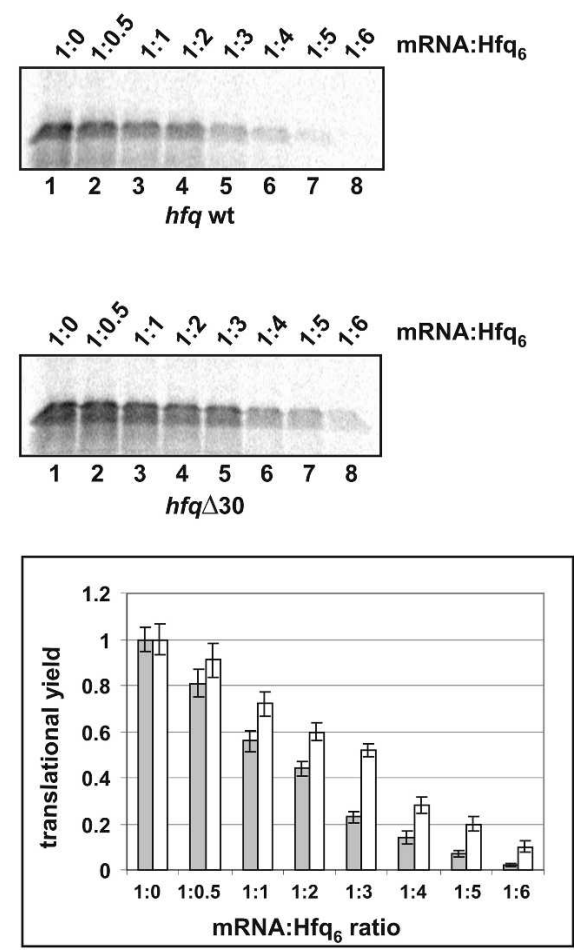

B

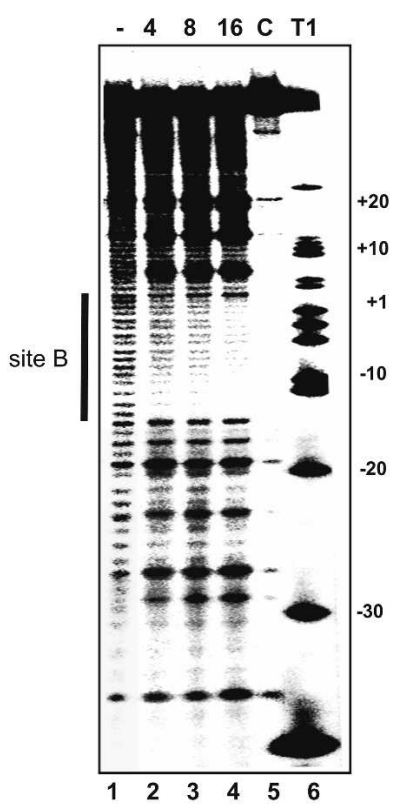

C

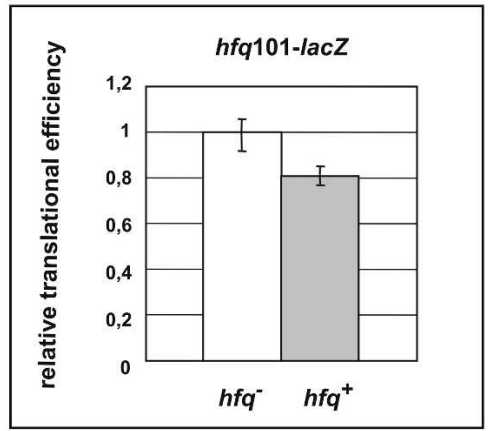

FIGURE 3. Both Hfq binding sites are necessary for efficient translational repression of $h f q$ mRNA. (A) In vitro translation of $h f q$ wild-type and $h f q \Delta 30$ mRNAs. Equimolar concentrations $(100 \mathrm{nM})$ of $h f q$ and $h f q \Delta 30$ mRNAs were used. The translation reactions with the individual mRNAs were carried out in the absence (lane 1) or in the presence of increasing molar amounts of Hfq. The protein was added to the reactions at molar $\mathrm{Hfq}_{6}$ ratios of 0.5:1 (lane 2), 1:1 (lane 3), 2:1 (lane 4), 3:1 (lane 5), 4:1 (lane 6), 5:1 (lane 7), and 6:1 (lane 8 ) to $h f q$ mRNA(s). The [ $\left.{ }^{14} \mathrm{C}\right]-$ labeled translation products were resolved by SDS-PAGE, and the gels were subjected to autoradiography. A graphical representation of three independent experiments is shown at the bottom. Error bars represent standard deviations. The translational yield of $h f q$ and of $h f q \Delta 30$ mRNAs is indicated by gray and white bars, respectively. The translational yield obtained with either mRNA in the absence of Hfq was set to 1. (B) Hydroxyl radical footprints of $h f q 96$ mRNA in the presence of Hfq. Samples containing $5^{\prime}$-end labeled $h f q 96$ mRNA were incubated in the absence (lane 1) or in the presence of Hfq (lanes 2-4) and subjected to hydroxyl radical cleavage. Hfq was added in fourfold (lane 2), eightfold (lane 3), and 16-fold (lane 4) molar excess ( $\mathrm{Hfq}_{6}$ excess) over $h f q 96$ mRNA. Lane 5 , untreated $h f q 96$ mRNA (5 nM) was incubated with Hfq (80 nM Hfq ${ }_{6}$ ). Lane 6, RNase T1 cleavage (G-specific cleavage) of $h f q 96$ mRNA. The region protected from hydroxyl-radical cleavage by Hfq (site B) is marked by a bar. Nucleotide positions in the $h f q$ mRNA sequence are shown at the right. $(C)$ Relative translational efficiency (see Materials and Methods) of the $h f q 101-l a c Z$ mRNA in a $h f q^{+}$and an $h f q^{-}$genetic background. The expression of the plasmid-encoded $h f q 101-l a c Z$ gene was

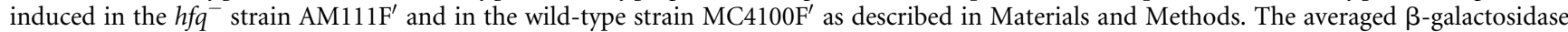
values normalized to mRNA levels obtained in the $h f q^{-}$strain (control) was set to 1 (white bar). The value obtained with the $h f q^{+}$strain (gray bar) was normalized to the control. The experiment was performed in duplicate. The error bars represent standard deviations.

The results obtained in this study strongly suggest that Hfq inhibits ribosome binding on its mRNA, and thus subsequent transit of ribosomes through the coding sequence, which should render the untranslated mRNA vulnerable to RNase E cleavage and would be expected to result in rapid functional inactivation of the mRNA (Iost and Dreyfus 1995; Baker and Mackie 2003). We have mapped in vitro several RNase E cleavage sites in the immediate coding region of $h f q$ mRNA (I. Moll, unpubl.), which would rationalize such a pathway for $h f q$ mRNA decay upon translational repression. Moreover, we have noticed that ribosome loading on $h f q$ mRNA in the presence of $\mathrm{Hfq}$ is only inhibited when $\mathrm{Hfq}$ is added prior to $30 \mathrm{~S}$ subunits (I. Moll, unpubl.). Thus, like for ompA mRNA (Vytvytska et al. 2000) mutually exclusive binding of either Hfq or ribosomes to $h f q$ mRNA appears to determine the fate of $h f q$ mRNA.

\section{MATERIALS AND METHODS}

\section{Bacterial strains and growth conditions}

The Escherichia coli strains MC4100F' (Steiner et al. 1993) and AM111F $^{\prime}$ (MC4100F' $h f q 1:: \Omega$; 33) have been described. They were grown in Luria-Bertani medium (Miller 1972) supplemented with ampicillin $(100 \mu \mathrm{g} / \mathrm{ml})$ where appropriate to maintain selection of plasmids.

\section{Construction of plasmids}

The plasmids pUhfqut and pUhfq $\Delta 30$ used as templates for in vitro mRNA synthesis were constructed as follows. The $h f q$ gene was placed under transcriptional control of the T7 $\Phi 10$ promoter by means of PCR. The forward primers A24 (5'-GCTCTAGATAA TACGACTCACTATAGGGTATCGTGCGCAATTTTTTCAGAATC 
GAAAGGTTC- $\left.3^{\prime}\right)$ and K25 (5'-GCTCTAGATAATACGA CTCAC TATAGGTTCAAAGTACAAATAAGCGTGTGAGGAAAAGAGAG AATG- $3^{\prime}$ ) contained a XbaI site (bold) and the T7 promoter sequence (underlined) either followed by the $5^{\prime}$-terminal part of the $5^{\prime}$-untranslated region (UTR) of the $h f q$ gene (corresponding to the transcriptional start of $h f q$ mRNA when transcribed from the P3 promoter; Tsui et al. 1996) (A24) or starting $30 \mathrm{nt}$ downstream of the $5^{\prime}$-end (K25). The sequence of the $h f q$ reverse primer B19 (5'-GGAATTCCCGTGTAAAAAAACAGCCCGAAAC- ${ }^{\prime}$ ) containing an EcoRI site (bold) is complementary to the sequence following the stop codon of the $h f q$ gene. The PCR products obtained with primers A24/B19 and K25/B19 were cleaved with XbaI and EcoRI, and ligated into the corresponding sites of plasmid pUC18, resulting in plasmids pUhfqwt and pUhfq $\Delta 30$, respectively.

Plasmids pRhfq131 and pRhfq101, which bear inducible $h f q-$ lac $Z$ translational fusion genes are derivatives of plasmid pRB381 (Brückner 1992). The PCR fragments comprising the lac promoter (from nucleotides -60 to +32 ) from plasmid pUHE21-2 (Lanzer and Bujard 1998) and the first $131 \mathrm{nt}(-68$ to +63$)$ or $101 \mathrm{nt}(-38$ to +63$)$ of the $h f q$ gene were inserted into the SalI and BamHI sites of plasmid pRB381. In the resulting plasmids, the corresponding $h f q-l a c Z$ mRNAs, which contain the first 21 codons of the $h f q$ gene fused to the eighth codon of the lacZ gene, are transcribed from the lac promoter.

\section{$\boldsymbol{\beta}$-galactosidase assays}

Strains AM111F $\left(h f q^{-}\right)$and $\mathrm{MC}^{\prime} 100 \mathrm{~F}^{\prime}\left(h q^{+}\right)$harboring plasmids pRhfq131 (hfq131-lacZ) or pRhfq101 (hfq101-lacZ) were incubated at $37^{\circ} \mathrm{C}$. At an $\mathrm{OD}_{600}$ of 0.4 , the plasmid encoded $h f q$-lac $Z$ genes were induced by addition of IPTG $(2 \mathrm{mM})$. Samples were withdrawn 30 min after induction to measure the $\beta$-galactosidase activities and for determination of the respective $h f q-l a c Z$ mRNA levels. The $\beta$-galactosidase activity was determined from triplicate samples as described (Miller 1972). The respective hfq-lacZ mRNA concentrations were determined by spotting total mRNA isolated from samples on a nitrocellulose membrane followed by hybridization with a $5^{\prime}$-end ${ }^{32}$-P]-labeled lacZ-specific probe $\left(5^{\prime}\right.$-TTTCCCGG GATCCCGTCGTTTTACAACGTCGTGACTGGGAA- $3^{\prime}$ ). The concentration of $5 \mathrm{~S}$ rRNA was likewise determined using a $5^{\prime}$-end $\left[{ }^{32}\right.$-P]labeled 5S RNA probe (5'-GGTGGGACCACCGCGCTACGGCCGC CAGGC- $3^{\prime}$ ) and served as an internal control. The signals were visualized by a PhosphorImager (Molecular Dynamics) and quantified by ImageQuant software. The relative $\beta$-galactosidase values shown in Figures 2 and 3 were obtained by normalization of the different $\beta$-galactosidase values to the amount of the respective $h f q$ lac $Z$ mRNAs. Two independent sets of experiments were performed.

\section{RNA constructs used in in vitro studies}

For $h f q$ mRNA synthesis, the plasmids pUhfqut and pUhfq $\Delta 30$ were used as templates for in vitro transcription with T7 RNA polymerase (Promega). To prepare full length $h f q$ mRNA, $h f q 126$ mRNA, and $h f q 76$ mRNA, the pUhfqut plasmid was cleaved with EcoRI, AflIII, and DdeI, respectively. Cleavage of plasmid pUhfq $\Delta 30$ with the same enzymes yielded templates for synthesis of $h f q \Delta 30, h f q 96$, and $h f q 46$ mRNAs. The run-off transcripts were purified on $6 \%$ polyacrylamide- $8 \mathrm{M}$ urea gels following standard procedures. The mRNA concentration was determined by measuring the $A_{260}$.

\section{Gel shift assays}

Gel-purified mRNAs were $5^{\prime}$-end labeled with $\left[\gamma^{-32} \mathrm{P}\right]$-ATP (Amersham Pharmacia Biotech) and again purified on $6 \%$ polyacrylamide-8M urea gels. Labeled mRNAs ( $5 \mathrm{nM}$ ) were incubated with or without increasing amounts of purified Hfq protein (as indicated in the legend to Fig. $2 \mathrm{~B}$ ) in a $10 \mu \mathrm{L}$ reaction in binding buffer (10 mM Tris at pH 7.5, $60 \mathrm{mM} \mathrm{NH}_{4} \mathrm{Cl}, 5 \mathrm{mM} \beta$-mercaptoethanol, $2 \mathrm{mM} \mathrm{MgOAc}, 100 \mathrm{ng}$ of yeast tRNA) for $5 \mathrm{~min}$ at $37^{\circ} \mathrm{C}$ and then for $10 \mathrm{~min}$ at $0^{\circ} \mathrm{C}$. The samples were then mixed with $40 \%$ glycerol to a final concentration of $10 \%$ and loaded on a native $4 \%$ polyacrylamide gel. Electrophoresis was performed in TAE buffer at $60 \mathrm{~V}$ for $12 \mathrm{~h}$. Radioactive bands were visualized using a PhosphorImager.

\section{Toeprinting analysis}

The $h f q$-specific mRNA used for toeprinting was obtained as follows. First, a PCR with primers A24 (5'-GCTCTAGATAATAC GACTCACTATAGGGTATCGTGCGCAATTTTTTCAGAATCGA AA- $\left.3^{\prime}\right)$ comprising the phage T7 $\Phi 10$ promoter and Y19 (5'-CC CTTGCAGCTT- $3^{\prime}$; complementary to nucletides +91 to +102 of $h f q$ mRNA) was performed using the pUhfqut template. Second, a run-off transcript was synthesized in vitro by T7 RNA polymerase. This $h f q$ transcript contained nucleotides -68 to +102 . The $\left[{ }^{32} \mathrm{P}\right]-$ $5^{\prime}$-end labeled oligonucleotides Y19 or F22 (5'-CACGTTCCCGA C- $3^{\prime}$; complementary to nucleotides +56 to +67 of $h f q$ mRNA) were annealed to $h f q$ mRNA (nucleotides -68 to +102 ) and used to prime cDNA synthesis by reverse transcriptase. The toeprinting assays were carried out with purified 30S ribosomal subunits and initiator-tRNA, tRNA $_{\mathrm{f}}^{\text {Met }}$, essentially as described by Hartz et al. (1988). The mRNA $(0.04 \mathrm{pmol})$ was pre-incubated at $37^{\circ} \mathrm{C}$ for $5 \mathrm{~min}$ with or without 2 pmol $30 \mathrm{~S}$ subunits and $10 \mathrm{pmol} \mathrm{tRNA}_{\mathrm{f}}^{\mathrm{Met}}$. To test the effect of Hfq on ternary complex formation, Hfq protein was added prior to the addition of $30 \mathrm{~S}$ subunits and $\mathrm{tRNA}_{\mathrm{f}}{ }^{\text {Met }}$ to the toeprinting reactions at the molar ratios to mRNA as specified in the legend to Figure 2.

\section{Hydroxyl radical footprinting}

$\left[{ }^{32} \mathrm{P}\right]-5^{\prime}$-end labeled $h f q 126$ or $h f q 96$ mRNA (5 nM each) and increasing amounts of Hfq-hexamer $(0 \mathrm{nM}, 20 \mathrm{nM}, 40 \mathrm{nM}$, and $80 \mathrm{nM}$ ) were mixed in the same manner as for the gel shift assay. After a 15 min incubation, the complex was subjected to hydroxyl radical cleavage. The radicals were generated using fresh $1 \mathrm{mM}$ diammonium iron (II) sulfate hexahydrate, $2 \mathrm{mM}$ EDTA, $1 \mathrm{mM}$ sodium ascorbate, and fresh $0.5 \%$ hydrogen peroxide (Tullius et al. 1986). The reaction was incubated for $1 \mathrm{~min}$ at room temperature and then quenched by addition of $10 \mathrm{mM}$ thiourea. After phenol extraction, the RNA was precipitated and analyzed on a $12 \%$ polyacrylamide- $8 \mathrm{M}$ urea gel.

\section{RNase T1 probing}

Unlabeled $h f q$ transcript $(0.1 \mathrm{pmol})$ containing nucleotides -68 to +102 (see toeprinting experiment) was hybridized to $0.2 \mathrm{pmol}\left[{ }^{32} \mathrm{P}\right]$ $5^{\prime}$-end labeled oligonucleotide Y19 by incubation in $50 \mathrm{mM}$ Tris$\mathrm{HCl}$ at $\mathrm{pH} 8.3,60 \mathrm{mM} \mathrm{NaCl}$, and $10 \mathrm{mM}$ DTT for $3 \mathrm{~min}$ at $85^{\circ} \mathrm{C}$ and snap freezing in liquid nitrogen. $\mathrm{MgCl}_{2}$ was added to a final concentration of $2 \mathrm{mM}$ and the incubation was continued for $5 \mathrm{~min}$ 
at $25^{\circ} \mathrm{C}$. Then 0.1 or 0.5 units of RNase $\mathrm{T} 1$ were added, and the incubation was continued for $5 \mathrm{~min}$ at $25^{\circ} \mathrm{C}$. The cDNA synthesis was performed in a total volume of $10 \mu \mathrm{L}$ with $1 \mathrm{U}$ of AMV reverse transcriptase (Promega) and $1 \mathrm{mM}$ of each dNTP for $15 \mathrm{~min}$ at $48^{\circ} \mathrm{C}$. After primer extension, the reactions were terminated by addition of $10 \mu \mathrm{L}$ loading buffer and by heating to $95^{\circ} \mathrm{C}$. The samples were analyzed on a $10 \%$ polyacrylamide- $8 \mathrm{M}$ urea gel.

\section{In vitro translation}

The full length $p p i B, h f q$, and $h f q \Delta 30$ mRNAs were translated in vitro using a S30 extract (Promega) as specified in the manufacturer's instructions. The translation reactions were incubated for $20 \mathrm{~min}$ at $37^{\circ} \mathrm{C}$ in the presence of $\left[{ }^{14} \mathrm{C}\right]$ lysine with or without addition of $\mathrm{Hfq}$ as indicated in Figures $2 \mathrm{~A}$ and $3 \mathrm{~A}$. The reactions were terminated by addition of four volumes of cold $90 \%$ acetone and placed on ice for $15 \mathrm{~min}$ followed by centrifugation at $10,000 \mathrm{~g}$ at $4^{\circ} \mathrm{C}$ for $10 \mathrm{~min}$. The pellets were dried, resuspended in $40 \mu \mathrm{L}$ protein loading buffer, and boiled for $5 \mathrm{~min}$ before loading onto a $12 \%$ SDS-polyacrylamide gel. The translation products were visualized by autoradiography.

\section{ACKNOWLEDGMENTS}

This work was supported by grant F1720 from the Austrian Science Fund (FWF) to U.B.

Received February 21, 2005; accepted March 16, 2005.

\section{REFERENCES}

Achsel, T., Stark, H., and Lührmann, R. 2001. The Sm domain is an ancient RNA-binding motif with oligo(U) specificity. Proc. Natl. Acad. Sci. 98: 3685-3689.

Argaman, L., Hershberg, R., Vogel, J., Bejerano, G., Wagner, E.G., Margalit, H., and Altuvia, S. 2001. Novel small RNA-encoding genes in the intergenic regions of Escherichia coli. Curr. Biol. 11: 941-950.

Arluison, V., Derreumaux, P., Allemand, F., Folichon, M., Hajnsdorf, E., and Regnier, P. 2002. Structural modelling of the Sm-like protein Hfq from Escherichia coli. J. Mol. Biol. 320: 705-712.

Baker, K.E. and Mackie, G.A. 2003. Ectopic RNase E sites promote bypass of $5^{\prime}$-end-dependent mRNA decay in Escherichia coli. Mol. Microbiol. 47: 75-88.

Baker, C.S., Morozov, I., Suzuki, K., Romeo, T., and Babitzke, P. 2002. CsrA regulates glycogen biosynthesis by preventing translation of $g l g C$ in Escherichia coli. Mol. Microbiol. 44: 1599-1610.

Brescia, C.C., Mikulecky, P.J., Feig, A.L., and Sledjeski, D.D. 2003. Identification of the Hfq-binding site on DsrA RNA: Hfq binds without altering DsrA secondary structure. RNA 9: 33-43.

Brown, L. and Elliott, T. 1996. Efficient translation of the RpoS $\sigma$ factor in Salmonella typhimurium requires host factor I, an RNAbinding protein encoded by the $h f q$ gene. J. Bacteriol. 178: $3763-$ 3770.

Brückner, R. 1992. A series of shuttle vectors for Bacillus subtilis and Escherichia coli. Gene 22: 187-192.

Christiansen, J.K., Larsen, M.H., Ingmer, H., Sogaard-Andersen, L., and Kallipolitis, B.H. 2004. The RNA-binding protein Hfq of Listeria monocytogenes: Role in stress tolerance and virulence. J. Bacteriol. 186: 3355-3362.

Ding, Y., Davis, B.M., and Waldor, M.K. 2004. Hfq is essential for Vibrio cholerae virulence and downregulates $\sigma^{\mathrm{E}}$ expression. Mol. Microbiol. 53: 345-354.
Dubey, A.K., Baker, C.S., Suzuki, K., Jones, A.D., Pandit, P., Romeo, T., and Babitzke, P. 2003. CsrA regulates translation of the Escherichia coli carbon starvation gene, $c s t A$, by blocking ribosome access to the cstA transcript. J. Bacteriol. 185: 4450-4460.

Folichon, M, Arluison, V., Pellegrini, O., Regnier, P., and Hajnsdorf, E. 2003. The poly(A) binding protein $\mathrm{Hfq}$ protects RNA from RNase E and exoribonucleolytic degradation. Nucleic Acids Res. 31: $7302-7310$.

Franze de Fernandez, M.T., Eoyang, L., and August, J.T. 1968. Factor fraction required for the synthesis of bacteriophage Q $\beta$-RNA. Nature 219: 588-590.

Geissmann, T.A. and Touati, D. 2004. Hfq, a new chaperoning role: Binding to messenger RNA determines access for small RNA regulator. EMBO J. 23: 396-405.

Hartz, D., McPheeters, D.S., Traut, R., and Gold, L. 1988. Extension inhibition analysis of translation initiation complexes. Methods Enzymol. 164: 419-425.

Iost, I. and Dreyfus, M. 1995. The stability of Escherichia coli lacZ mRNA depends upon the simultaneity of its synthesis and translation. EMBO J. 14: 3252-3261.

Kajitani, M., Kato, A., Wada, A., Inokuchi, Y., and Ishihama, A. 1994. Regulation of the Escherichia coli hfq gene encoding the host factor for phage Q $\beta$. J. Bacteriol. 176: 531-534.

Lanzer, M. and Bujard, H. 1998. Promoters largely determine the efficiency of repressor action. Proc. Natl. Acad. Sci. 85: 8973-8977.

Massé, E. and Gottesman, S. 2002. A small RNA regulates the expression of genes involved in iron metabolism in Escherichia coli. Proc. Natl. Acad. Sci. 99: 4620-4625.

Massé, E., Escorcia, F.E., and Gottesman, S. 2003. Coupled degradation of a small regulatory RNA and its mRNA targets in Escherichia coli. Genes \& Dev. 19: 2374-2383.

Mathews, D.H., Sabina, J., Zuker, M., and Turner, D.H. 1999. Expanded sequence dependence of thermodynamic parameters improves prediction of RNA secondary structure. J. Mol. Biol. 288: 911-940.

Miller, J. H. 1972. Experiments in molecular genetics. Cold Spring Harbor Laboratory, Cold Spring Harbor, NY.

Moll, I., Afonyushkin, T., Vytvytska, O., Kaberdin, V.R., and Bläsi, U. 2003a. Coincident Hfq binding and RNase E cleavage sites on mRNA and small regulatory RNAs. RNA 9: 1308-1314.

Moll, I., Leitsch, D., Steinhauser, T., and Bläsi, U. 2003b. RNA chaperone activity of the Sm-like Hfq protein. EMBO Rep. 4: 284-289.

Møller, T., Franch, T., Hojrup, P., Keene, D.R., Bachinger, H.P., Brennan, R.G., and Valentin-Hansen, P. 2002. Hfq: A bacterial Sm-like protein that mediates RNA-RNA interactions. Mol. Cell 9: 23-30.

Muffler, A., Fischer, D., and Hengge-Aronis, R. 1996. The RNAbinding protein HF-I, known as a host factor for phage Q $\beta$ RNA replication, is essential for the translational regulation of rpoS in Escherichia coli. Genes \& Dev. 10: 1143-1151.

Nikulin, A., Stolboushkina, E., Perederina, A., Vassilieva, I., Bläsi, U., Moll, I., Kachalova, G., Yokoyama, S., Vassylyev, D., Garber, M. et al. 2005. The crystal structure of Pseudomonas aeruginosa Hfa protein. Acta Cryst. D. 61: 141-146.

Philippe, C., Eyermann, F., Benard, L., Portier, C., Ehresmann, B., and Ehresmann, C. 1993. Ribosomal protein S15 from Escherichia coli modulates its own translation by trapping the ribosome on the mRNA initiation loading site. Proc. Natl. Acad. Sci. 90: 4394-4398.

Robertson, G.T. and Roop Jr., R.M. 1999. The Brucella abortus host factor I (HF-I) protein contributes to stress resistance during stationary phase and is a major determinant of virulence in mice. Mol. Microbiol. 34: 690-700.

Romby, P. and Springer, M. 2003. Bacterial translational control at atomic resolution. Trends Genet. 19: 155-161.

Sauter, C., Basquin, J., and Suck, D. 2003. Sm-like proteins in Eubacteria: The crystal structure of the Hfq protein from Escherichia coli. Nucleic Acids Res. 31: 4091-4098.

Schlax, P.J., Xavier, K.A., Gluick, T.C., and Draper, D.E. 2001. Translational repression of the Escherichia coli $\alpha$-operon mRNA: 


\section{Večerek et al.}

Importance of an mRNA conformational switch and a ternary entrapment complex. J. Biol. Chem. 276: 38494-38501.

Schumacher, M.A., Pearson, R.F., Møller, T., Valentin-Hansen, P., and Brennan, R.G. 2002. Structures of the pleiotropic translational regulator Hfq and Hfq-RNA complex: A bacterial Sm-like protein. EMBO J. 21: 3546-3556.

Senear, A.W. and Steitz, J.A. 1976. Site-specific interaction of Q $\beta$ host factor and ribosomal protein S1 with $Q \beta$ and R17 bacteriophage RNAs. J. Biol. Chem. 251: 1902-1912.

Sledjeski, D.D., Whitman, C., and Zhang, A. 2001. Hfq is necessary for regulation by the untranslated RNA DsrA. J. Bacteriol. 183: 1997-2005.

Sonnleitner, E., Hagens, S., Rosenau, F., Wilhelm, S., Habel, A., Jäger, K.E., and Bläsi, U. 2003. Reduced virulence of a $h f q$ mutant of Pseudomonas aeruginosa O1. Microb. Pathog. 35: 217-228.

Steiner, M., Lubitz, W., and Bläsi, U. 1993. The missing link in phage lysis of gram-positive bacteria: Gene 14 of Bacillus subtilis phage Phi29 encodes the functional homolog of $\lambda \mathrm{S}$ protein. J. Bacteriol. 175: $1038-1042$.

Tsui, H.C. and Winkler, M.E. 1994. Transcriptional patterns of the mutL-miaA superoperon of Escherichia coli K-12 suggest a model for posttranscriptional regulation. Biochimie 76: 1168-1177.

Tsui, H.C., Leung, H.C., and Winkler, M.E. 1994. Characterization of broadly pleiotropic phenotypes caused by an $h f q$ insertion mutation in Escherichia coli K-12. Mol. Microbiol. 13: 35-49.

Tsui, H.C., Feng, G., and Winkler, M.E. 1996. Transcription of the mutL repair, miaA tRNA modification, $h f q$ pleiotropic regulator, and hflA region protease genes of Escherichia coli K-12 from clustered $\sigma 32$-specific promoters during heat shock. J. Bacteriol.
178: 5719-5731.

Tsui, H.C., Feng, G., and Winkler, M.E. 1997. Negative regulation of $m u t S$ and $m u t H$ repair gene expression by the Hfq and RpoS global regulators of Escherichia coli K-12. J. Bacteriol. 179: 7476-7487.

Tullius, T.D. and Dombroski, B.A. 1986. Hydroxyl radical "footprinting": High-resolution information about DNA-protein contacts and application to $\lambda$ repressor and Cro protein. Proc. Natl. Acad. Sci. 83: 5469-5473.

Valentin-Hansen, P., Eriksen, M., and Udesen, C. 2004. The bacterial Sm-like protein Hfq: A key player in RNA transactions. Mol. Microbiol. 51: 1525-1533.

Večerek, B., Moll, I., Afonyushkin, T., Kaberdin, V., and Bläsi, U. 2003. Interaction of the RNA chaperone Hfq with mRNAs: Direct and indirect roles of Hfq in iron metabolism of Escherichia coli. Mol. Microbiol. 50: 897-909.

Vytvytska, O., Jakobsen, J.S., Balcunaite, G., Andersen, J.S., Baccarini, M., and von Gabain, A. 1998. Host factor I, Hfq, binds to Escherichia coli ompA mRNA in a growth rate-dependent fashion and regulates its stability. Proc. Natl. Acad. Sci. 95: 14118-14123.

Vytvytska, O., Moll, I., Kaberdin, V. R., von Gabain, A., and Bläsi, U. 2000. Hfq (HF1) stimulates ompA mRNA decay by interfering with ribosome binding. Genes \& Dev. 14: 1109-1118.

Zhang, A., Wassarman, K.M., Ortega, J., Steven, A.C., and Storz, G. 2002. The Sm-like Hfq protein increases OxyS RNA interaction with target mRNAs. Mol. Cell 9: 1-20.

Zhang, A., Wassarman, K.M., Rosenow, C., Tjaden, B.C., Storz, G., and Gottesman, S. 2003. Global analysis of small RNA and mRNA targets of Hfq. Mol. Microbiol. 50: 1111-1124. 

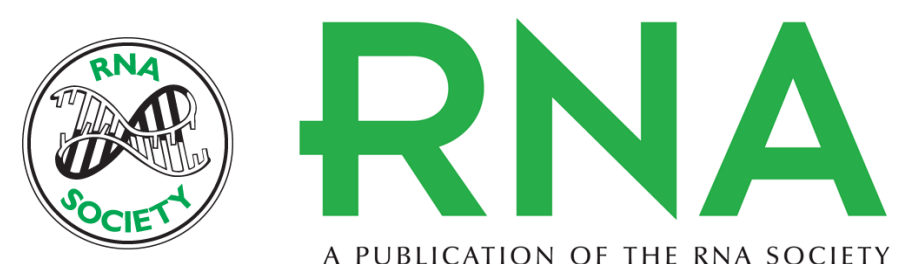

A PUBLICATION OF THE RNA SOCIETY

\section{Translational autocontrol of the Escherichia coli hfq RNA chaperone gene}

BRANISLAV VECEREK, ISABELLA MOLL and UDO BLÄSI

RNA 2005 11: 976-984

References This article cites 45 articles, 20 of which can be accessed free at:

http://rnajournal.cshlp.org/content/11/6/976.full.html\#ref-list-1

\section{License}

Email Alerting Receive free email alerts when new articles cite this article - sign up in the box at the Service top right corner of the article or click here. 